\title{
The Effect of Firework Explosion at the Fireworks Factory on Air Pollutant Levels
}

\author{
Seher Palanbek Yavaş, ${ }^{1}$ (i) Caner Baysan, ${ }^{2}$ 늘 Ayşe Emel Önal'
}

${ }^{1}$ Department of Public Health, Division of Environmental Health, Istanbul University Faculty of Medicine, Istanbul, Turkey ${ }^{2}$ Department of Public Health, Division of Epidemiology Ankara University Faculty of Medicine, Ankara, Turkey

\section{ABSTRACT}

Objectives: Fireworks are used for show and entertainment purposes during celebrations of special days in many countries. However, fireworks negatively affect human health in many ways, especially air pollution. After the explosion of the fireworks factory in Sakarya, this study investigated the changes in the air pollutants in the region.

Methods: The firework factory exploded on 3 July 2020. This date was the determiner, and daily air quality data (particulate matter with a diameter of $<2.5 \mu \mathrm{m}\left(\mathrm{PM}_{2.5}\right)$, nitrogen dioxide $\left(\mathrm{NO}_{2}\right)$, nitroxide $\left(\mathrm{NO}_{\mathrm{x}}\right)$, carbon monoxide (CO), sulfur dioxide $\left(\mathrm{SO}_{2}\right)$, and ozone $\left(\mathrm{O}_{3}\right)$ ) were collected 1 week before (26 June-2 July) and 1 week later (3-9 July). Air quality monitoring data were received from four air monitoring stations (Ozanlar, Merkez, Sakarya, and Hendek) in Sakarya.

Results: Of the pre-explosion median, $\mathrm{PM}_{2.5}$ increased from 12.1 [12.9] to 18.2 [35.9] $\mu \mathrm{g} / \mathrm{m}^{3}(50.4 \%), \mathrm{SO}_{2}$ from 8.5 [2.8] to 12.1 [13.0] $\mathrm{\mu g} / \mathrm{m}^{3}$ (42.4\%) ( $\mathrm{p}=0.010$ and $\mathrm{p}=0.010$, respectively). $\mathrm{NO}_{\mathrm{x}}$ decreased from 45.9 [29.1] to 42.1 [51.1], $\mathrm{O}_{3}$ increased from 21.6 [29.4] to 46.5 [33.8], CO from 1388.6 [209.2] to 1436.2 [93.4] ( $p=0.224$, $p=0.678$ and $p=0.225$, respectively).

Please cite this article as: Palanbek Yavaş S, Baysan C, Önal AE. The Effect of Firework Explosion at the Fireworks Factory on Air Pollutant Levels. Anatol J Family Med 2021;4(1):80-84.

Address for correspondence: Dr. Caner Baysan. Department of Public Health, Division of Epidemiology Ankara University Faculty of Medicine, Ankara, Turkey

Phone: +90 5057792642

E-mail: canerbaysan@gmail.com

Received Date: 17.08.2020

Accepted Date: 21.12.2020

Published online: 10.03 .2021

(C) Copyright 2021 by Anatolian Journal of Family Medicine Available online at Www.anatoljfm.org

OPEN ACCESS

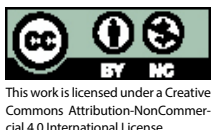

Conclusion: This study suggests that the explosion of the fireworks factory led to short-term air pollution in the area. Thus, it may be appropriate to consider the potential health effects of air pollution in the studies to be carried out.

Keywords: Particulate matter, air pollutants, explosions, sulfur dioxide

\section{INTRODUCTION}

Fireworks are low-explosive celebration tools used widely and popularly in festivals (e.g., Festival of Lights (Diwali) in India and Lantern Festival in Taiwan), in carnivals, on special days (e.g., Bastille Day in France, Bonfire Night in England, Independence Day in the USA, and Canada Day), and in organizations (e.g., weddings and sports competitions). In addition to being a mesmerizing entertainment show for people for centuries, fireworks also constitute a cultural heritage for many countries. ${ }^{[1]}$ Furthermore, fireworks were first created in China by mixing potassium nitrite, charcoal, and sulfur. However, fireworks, in addition to carbon and sulfur necessary for ignition, contain stabilizers, oxidizers (e.g., arsenic, manganese, sodium oxalate, aluminum, iron powder, potassium perchlorate, strontium nitrate, and barium nitrate), and additional coloring. Accordingly, with the explosion of fireworks, sulfur dioxide $\left(\mathrm{SO}_{2}\right)$, carbon dioxide $\left(\mathrm{CO}_{2}\right)$, carbon monoxide $(\mathrm{CO})$, and particulate matter $(\mathrm{PM})$, which are all very air pollutant gases, are released into the air along with metal salts (aluminum, cadmium, and etc.). The contaminants caused by fireworks usually get overlooked because the emissions caused 
by industries and transportation remain at the forefront of the air pollution agenda. However, studies determined that the ignition of fireworks causes short-term air pollution and health effects. ${ }^{[2]}$ Furthermore, a compilation study showed that the sharpest increases in concentrations of air contaminants (2-8 times more) happen during the show and right afterward. Moreover, they generally decrease back gradually to previous levels after 24 hours. In addition, the smoke caused by the ignition of fireworks reduces visibility at rate of $92 \% .{ }^{[3]}$ Thus, the presence of PM, metal elements ( $\mathrm{Mg}, \mathrm{Al}, \mathrm{Fe}, \mathrm{Zn}$, and etc.), and water-soluble ions $\left(\mathrm{K}^{+}, \mathrm{Cl}^{-}, \mathrm{SO}_{4}^{2-}\right.$, and etc.) in the air increased with the use of fireworks in various celebrations in Spain (Sant Joan fiesta), Italy (World Cup Celebration), India (Light Festival), Taiwan (Lantern Festival), and China (Spring Festival). ${ }^{[4-8]}$

Fireworks increase air pollution and are detrimental to people with previous respiratory diseases (e.g., asthma, chronic obstructive lung disease, chemical sensitivity, and etc.), and the contaminants may cause the worsening of the disease and increase the symptoms (e.g., shortness of breath, cough, and chest pain). Moreover, the bad air quality caused by fireworks may cause many illnesses (e.g., headache, anxiety, heart attack, hypertension, laryngitis, and pneumonia) even for people who do not have existing illnesses. ${ }^{[2,3,9]}$ In addition, exposure to short-term air pollution, such as the one caused by fireworks, has been linked to cardiovascular mortality that is not caused by respiration and accident. Consequently, children and elderly people are more sensitive to expiration caused by acutely increased contaminant concentrations. ${ }^{[1]}$ In Japan, a case of acute eosinophilic pneumonia was reported as a result of breathing firework smoke three nights in a row. ${ }^{[10]}$ Furthermore, a study conducted in Philadelphia has shown that exposure to high-level PM concentrations caused by fireworks caused a fatal asthma exacerbation in one of two children and a near-fatal one for the other during the Independence Day celebration. ${ }^{[11]}$ However, several studies conducted on fireworks in Turkey refer to their use in historical periods, injuries caused by fireworks, and their effects on fauna. ${ }^{[12-14]}$ In the latest published study, the level of indoor air contamination through PM and metals have been studied in wedding halls that used torches. ${ }^{[15]}$ However, this study tried to assess the seasonal levels of air pollution in Sakarya and the effects of the firework explosion that has occurred on this level.

\section{METHOD}

The city of Sakarya, located in the Marmara Region of Turkey, is 482.109 .70 hectare with a population of 1.029.650 (year, 2019) $\left(40^{\circ} 49^{\prime} 22^{\prime \prime K} / 30^{\circ} 23^{\prime} 40^{\prime \prime D}\right) .^{[16]}$ On 3 July 2020, an explosion occurred in a firework factory located in the
Hendek district of Sakarya. After the explosion, intense amounts of dust and smoke became visible. ${ }^{[17]}$ Four stations within the national air quality monitoring network in the city of Sakarya are affiliated to the Ministry of Environment and Urbanisation (Ozanlar, Central, Sakarya, and Hendek) (Fig. 1). This study utilized 3 July 2020, the day of the explosion of the firework factory, as the determiner. Air quality data (PM with a diameter of $<2.5 \mu \mathrm{m}\left(\mathrm{PM}_{2.5}\right)$, nitrogen dioxide $\left(\mathrm{NO}_{2}\right)$, nitroxide $\left(\mathrm{NO}_{\mathrm{x}}\right), \mathrm{CO}, \mathrm{SO}_{2}$, and ozone $\left.\left(\mathrm{O}_{3}\right)\right)$ were obtained from 26 June to 2 July (pre-explosion) and 3 to 9 July (post-explosion). ${ }^{[18]}$

The mean, standard deviation, median and interquartile range of the daily air contaminant data of the four measurement stations were carried out. Moreover, the conformity of the continuous variables to the normal distribution was evaluated using visual (histogram and probability graphics) and analytic methods (Shapiro-Wilk tests). Consequently, the Wilcoxon test was employed to evaluate the dependent pairs if the continuous variables do not conform to the normal distribution. A p-value less than 0.05 was considered significant.

\section{RESULTS}

The PM2.5 value showed an increase of as much as $50.4 \%$ before the explosion which was statistically significant $(p=0.010)$. Similarly, a statistically significant increase of $42.4 \%$ was shown when the $\mathrm{SO}_{2}$ situation changed after the explosion $(p=0.010)$. The relationship between exposure before and after air quality parameters change is summarized in Table 1. The maximum $\mathrm{NO}_{x}$ measurement value measured before and after the explosion were $82.2 \mu \mathrm{g} / \mathrm{m}^{3}$ and $110.9 \mu \mathrm{g} / \mathrm{m}^{3}$, respectively. An increase of $24.5 \%(7.71$ $\mu \mathrm{g} / \mathrm{m}^{3}$ ) was observed in the $\mathrm{O}_{3}$ median value after the explosion when the $\mathrm{O}_{3}$ change was evaluated before and af-

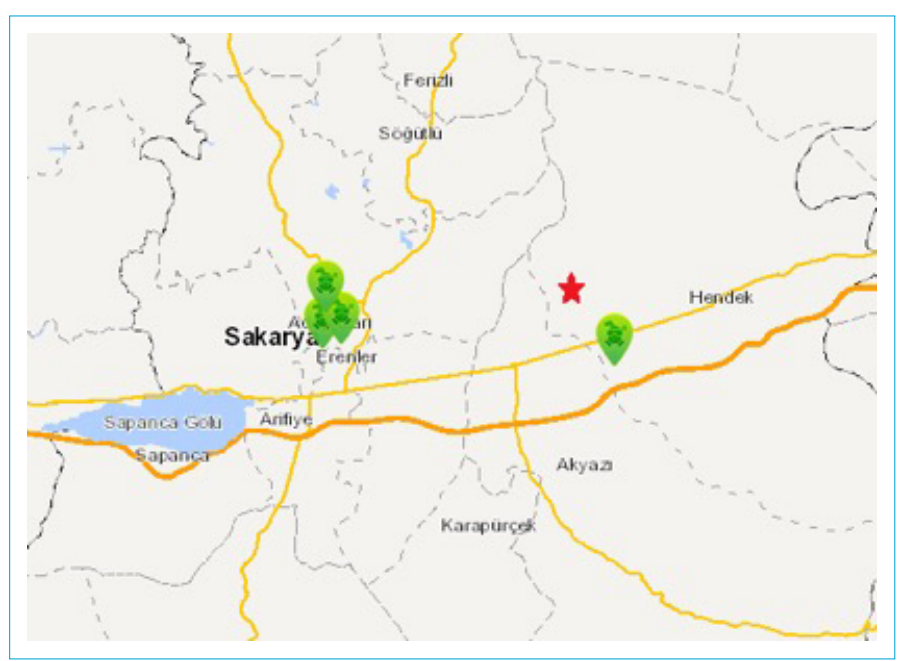

Figure 1. Stations located in Sakarya and the factory in which the explosion occurred. 


Table 1. The relationship between exposure before and
after air quality parameters change
\begin{tabular}{lccc} 
Air Quality Parameters & Before Exposure & After Exposure & $\mathbf{p}$ \\
\hline $\mathrm{PM}_{10}\left(\mu \mathrm{g} / \mathrm{m}^{3}\right)$ & $29.7[10.3]$ & $29.5[10.8]$ & 0.507 \\
$\mathrm{PM}_{2.5}\left(\mu \mathrm{g} / \mathrm{m}^{3}\right)$ & $12.1[12.9]$ & $18.2[35.9]$ & 0.010 \\
$\mathrm{SO}_{2}\left(\mu \mathrm{g} / \mathrm{m}^{3}\right)$ & $8.5[2.8]$ & $12.1[13.0]$ & 0.010 \\
$\mathrm{CO}\left(\mu \mathrm{g} / \mathrm{m}^{3}\right)$ & $1388.6[209.2]$ & $1436.2[93.4]$ & 0.225 \\
$\mathrm{NO}_{2}\left(\mu \mathrm{g} / \mathrm{m}^{3}\right)$ & $21.6[24.5]$ & $18.7[24.3]$ & 0.355 \\
$\mathrm{NO}_{x}\left(\mu \mathrm{g} / \mathrm{m}^{3}\right)$ & $45.9[29.1]$ & $42.1[51.1]$ & 0.224 \\
$\mathrm{O}_{3}\left(\mu \mathrm{g} / \mathrm{m}^{3}\right)$ & $21.6[29.4]$ & $46.5[33.8]$ & 0.678
\end{tabular}

CO: Carbon monoxide; $\mathrm{NO}_{2}$ : Nitrogen dioxide; $\mathrm{NO}_{x}$ : Nitroxide; $\mathrm{O}_{3}$ : Ozone; $\mathrm{PM}_{2.5}$ : Particulate matter with a diameter of $<2.5 \mu \mathrm{m} ; \mathrm{PM}_{10}$ : Particulate matter with a diameter of $\angle 10 \mu \mathrm{m} ; \mathrm{SO}_{2}$ :Sulfur dioxide.

Data is presented as median [IQR].

Wilcoxon Test.

ter the explosion $(p=0.678)$. The minimum and maximum $\mathrm{O}_{3}$ values after the explosion were $16.5 \mu \mathrm{g} / \mathrm{m}^{3}$ and $65.2 \mu \mathrm{g} /$ $\mathrm{m}^{3}$. Consequently, a statistically insignificant increase was noted when the $\mathrm{CO}$ measurement value after the explosion was evaluated compared with before the explosion $(p=0.225)$. Furthermore, the minimum and maximum $\mathrm{CO}$ measurements were $1271.9 \mu \mathrm{g} / \mathrm{m}^{3}$ and $1517.2 \mu \mathrm{g} / \mathrm{m}^{3}$.

The $\mathrm{NO}_{2}$ after the explosion decreased from 21.6 [24.5] to 18.7 [24.3] compared with before the explosion ( $p=0.678)$. The daily graphics of $\mathrm{PM}_{2.5}$ peaked twice on 4 and 7 July. PM2.5 peaked median values were on 4th of July 47.9 [20.4] $\mu \mathrm{g} / \mathrm{m}^{3}$ and $7^{\text {th }}$ of July 44.2 [15.2] $\mu \mathrm{g} / \mathrm{m}^{3}$ and, $\mathrm{PM}_{2.5}$ levels before and after the explosion are shown in Figure 2. Consequently, $\mathrm{SO}_{2}$ reached its highest mean value of $18.6 \pm 8.7$ $\mu \mathrm{g} / \mathrm{m}^{3}$ on 6 July. $\mathrm{SO}_{2}$ levels before and after the explosion are shown in Figure 3.

\section{DISCUSSION}

The levels of seven air contaminants showed different tendencies after the explosion in the firework factory. When air pollutant measurement values were evaluated before and after explosion, it was found that $\mathrm{PM}_{2.5}$ and $\mathrm{SO}_{2}$ measurement values increased in this study. Similarly, the $\mathrm{PM}_{2.5}$ levels at the nearest station where the fireworks were fired could rise to $500 \mu \mathrm{g} / \mathrm{m}^{3}$ per hour when the air pollution caused by fireworks during the Independence Day celebrations in the USA was investigated. Thus, it increased by 48 $\mu \mathrm{g} / \mathrm{m}^{3}$ (370\%) in 24-h measurements. ${ }^{[19]}$ On the one hand, in a study conducted in China, the $\mathrm{PM}_{2.5}$ concentrations measured during the festival in 2013, 2014, 2015, 2016, and 2017 were determined to be $79 \mu \mathrm{g} / \mathrm{m}^{3}$ (highest, $524 \mu \mathrm{g} / \mathrm{m}^{3}$ ), $94 \mu \mathrm{g} / \mathrm{m}^{3}$ (highest, $290 \mu \mathrm{g} / \mathrm{m}^{3}$ ), $53 \mu \mathrm{g} / \mathrm{m}^{3}$ (highest, $163 \mu \mathrm{g} /$ $\mathrm{m}^{3}$ ), $50 \mu \mathrm{g} / \mathrm{m}^{3}$ (highest, $146 \mu \mathrm{g} / \mathrm{m}^{3}$ ), and $32 \mu \mathrm{g} / \mathrm{m}^{3}$ (highest,

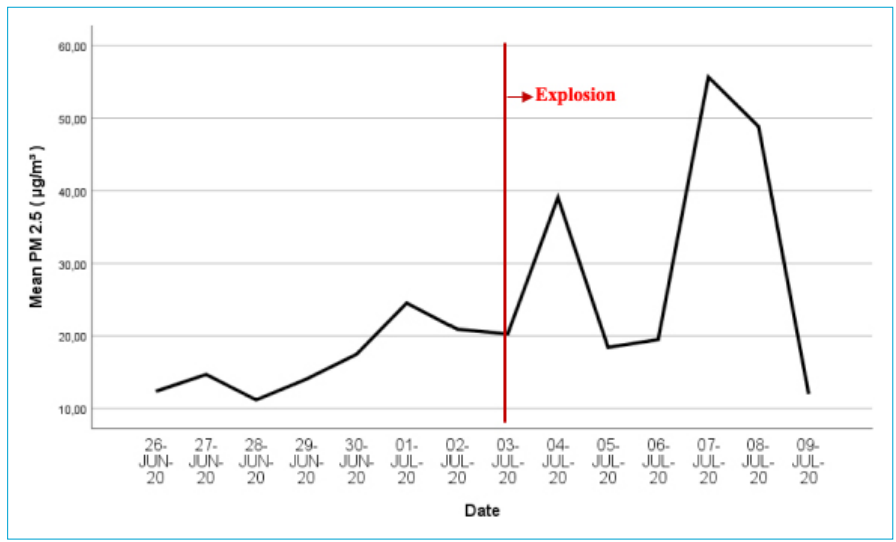

Figure 2. $\mathrm{PM}_{2.5}$ levels before and after the explosion.

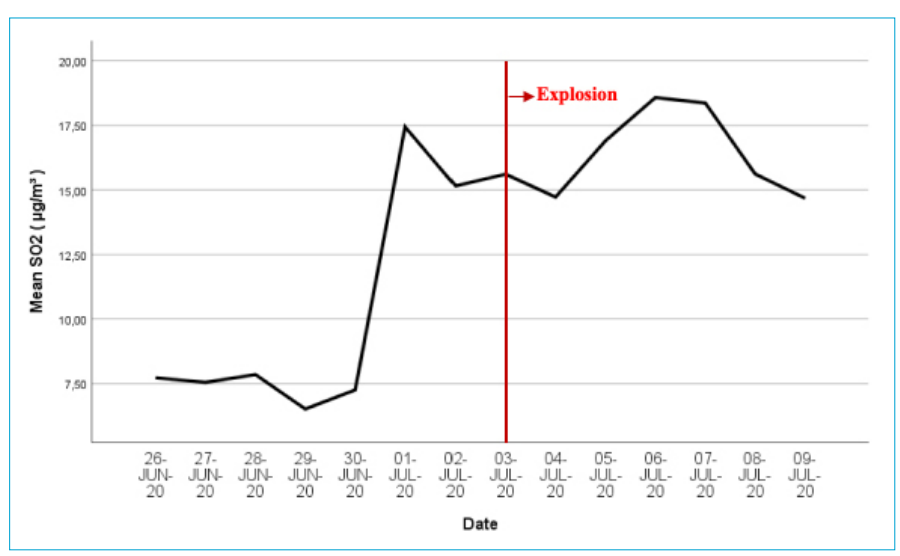

Figure 3. $\mathrm{SO}_{2}$ levels before and after the explosion.

$\left.156 \mu \mathrm{g} / \mathrm{m}^{3}\right)$, respectively. ${ }^{[8]}$ Similarly, in a study conducted in certain regions of Mexico during the new year celebrations, the $\mathrm{PM}_{2.5}$ levels reached up to $200 \mu \mathrm{g} / \mathrm{m}^{3}$. The highest recorded level was $690 \mathrm{\mu g} / \mathrm{m}^{3}$ in 2015 in a residential area near the city center. ${ }^{[20]}$

This study found an insignificant decrease in the $\mathrm{NO}_{2}$ value from $21.6 \mu \mathrm{g} / \mathrm{m}^{3}$ to $18.7 \mu \mathrm{g} / \mathrm{m}^{3}$. Moreover, $\mathrm{NO}_{2}$ can be indirectly affected by many factors, particularly traffic and industry emissions. Fireworks ignition may affect the $\mathrm{NO}_{2}$ concentrations as well. However, $\mathrm{NO}_{2}$ is less sensitive to the firework effect compared with the primary contaminant types. Also, $\mathrm{NO}_{2}$ in the atmosphere may easily oxidize to $\mathrm{NO}_{3}$ and can be more dominantly found in atmospheric aerosols in this manner. ${ }^{[8]}$ This maybe the reason that a sensitive increase after the explosion was not seen.

In a study conducted in India, the 24 hours concentrations of the air contaminants during the Festival of Lights was determined to be $139.1 \mu \mathrm{g} / \mathrm{m}^{3}$ (1.95-6.59 times higher) and $107.3 \mu \mathrm{g} / \mathrm{m}^{3}$ (1.79-5.67 times higher) for $\mathrm{SO}_{2}$ and $\mathrm{NO}_{\mathrm{x}^{\prime}}$ respectively. ${ }^{\left[{ }^{[9]}\right.}$ Furthermore, in a study conducted in the Kolkata metropole of India, the $\mathrm{SO}_{2}$ levels measured during the day and night at the time of the festival were 46 
$\mu \mathrm{g} / \mathrm{m}^{3}$ (3 times higher than the normal level) and $84 \mu \mathrm{g} / \mathrm{m}^{3}$ (5 times higher), respectively. ${ }^{[21]}$ In another study conducted in Spain, the levels of $\mathrm{PM}, \mathrm{SO}_{2}$ and $\mathrm{NO}_{x}$ have increased during the firework shows. ${ }^{[22]}$ As follows in our study it has been determined that $\mathrm{SO}_{2}$ level has increased statistically significant and $\mathrm{NO}_{\mathrm{x}}$ level has decreased but this result was not statistically significant.

An increase in the level of $\mathrm{O}_{3}$ was also observed after the fireworks explosion, which was not statistically significant, this increase may explain the small change in the level of $\mathrm{NO}_{x}$. Moreover, $\mathrm{O}_{3}$ may be given as an example of secondary contaminants that form photochemically. Furthermore, in the study conducted in the Kannur region of India, $\mathrm{O}_{3}$ concentration has been found to increase by $69 \%$ and $113 \%$ on festival days (Vishu Day). In addition, the $\mathrm{NO}_{2}$ level increased, unlike in the present study, and this change may be related to the $\mathrm{NO}_{2}$ photolysis rates shown in the modeling. ${ }^{[23]}$

In recent years, the chemical components released into the atmosphere from various sources caused air pollution of PM indifferent sizes as one of the problems of utmost importance in terms of public health that needs to be solved. ${ }^{[24]}$ The United Nations International Children's Emergency Fund published a report indicating that 600.0000 children die each year in developing countries due to insufficient air quality. ${ }^{[25]}$ Moreover, in a study conducted in China, the rates for cardiovascular and respiratory disease related mortality attributed to air pollution were determined as $0.36 \%$ and $0.42 \%$, respectively. ${ }^{[26]}$ Thus, $^{\mathrm{PM}_{2.5}}$, found to be significantly high in the current study, increases the strain of morbidity related to exercise-induced asthma and bronchitis. Moreover, $\mathrm{SO}_{2}$ increases hospital visits and hospitalizations due to bronchial asthma, bronchitis, and pneumonia. ${ }^{[27,28]}$

As the limitation of our research in order to have more representation in the region, the number of stations must be high and the data must be fully entered in to the system. However, this research was conducted using air quality data provided by the Ministry of Environment and Urbanization and no measurements were made by the researcher. In addition, the data presented did not contain heavy metal measurements.

\section{CONCLUSION}

No festivals in Turkey are celebrated with the involvement of intensive long-term use of fireworks within the scope of cultural activities and traditions. However, firework shows can be observed in various regions of the country at different times such as during new year celebrations and special days (birthdays, openings, and etc.) even if it is not collective. This maybe the reason for the lack of a firework-related air pollution assessment in Turkey. However, the explosion that occurred in the firework factory increases air pollution in the region with the potential for the occurrence of health effects (increase in hospitalizations, asthma attacks, heart attacks, and etc.). ${ }^{[29]}$ Thus, a study must be conducted in the future on the short-term air pollution caused by fireworks in cities where many entertainments and showing venues (Istanbul, Antalya, and etc.) exist. Additionally, the health effects of the people living in that region must be evaluated.

\section{Disclosures}

Peer-review: Externally peer-reviewed.

Conflict of Interest: None declared.

Ethics Committee Approval: The permission from an ethics committee is not required to conduct (Istanbul University Social and Human Sciences Research Ethics Committee, Decision date: Dec 07,2020 and Decision number: 67937).

Authorship Contributions: Concept - S.P.Y., C.B.; Design - S.P.Y., C.B.; Supervision -A.E.U.; Materials - S.P.Y.,C.B.; Data collection \&/or processing - S.P.Y.,C.B.; Analysis and/or interpretation - C.B.; Literature search - S.P.Y.,C.B.; Writing - S.P.Y.,C.B.; Critical review -A.E.U.

\section{REFERENCES}

1. Greven F, Vonk JM, Fischer4 P, Duijm F, Vink NM, Brunekreef B. Air pollution during New Year's fireworks and daily mortality in the Netherlands. Sci Rep 2019;9(1):5735. [CrossRef]

2. Gouder $\mathrm{C}$, Montefort S. Potential impact of fireworks on respiratory health. Lung India 2014;31(4):375-9. [CrossRef]

3. Singh $A$, Pant $P$, Pope FD. Air quality during and after festivals: Aerosol concentrations, composition and health effects. Atmos Res 2019;227:220-32. [CrossRef]

4. Moreno T, Querol X, Alastuey A, Amato F, Pey J, Pandolfi M, et al. Effect of fireworks events on urban back ground trace metal aerosol concentrations: is the cocktail worth the show? $J$ Hazard Mater 2010;183(1):945-9. [CrossRef]

5. Vecchi $R$, Bernardoni V, Cricchio $D$, Alessandro $A D$, Fermo $P$, Lucarelli $F$, et al. The impact of fireworks on airborne particles. Atmos. Environ 2008:42(6);1121-32. [CrossRef]

6. Barman SC, Singh R, Negi MPS, Bhargava SK. Ambient air quality of Lucknow City (India) during use of fireworks on Diwali Festival. Environ Monit Assess 2008;137(1-3):495-504. [CrossRef]

7. Do TM, Wang CF, Hsieh YK, Hsieh HF. Metals present in ambient air before and after a firework festival in Yanshui, Tainan, Taiwan. Aerosol Air Qual Res 2012;12(5):981-93. [CrossRef]

8. Song $Y$, Wan $X$, Bai $S$, et al. The characteristics of air pollutants during two distinct episodes of fireworks burning in a valley city of north China. PLoS One 2017;12(1):e0168297. [CrossRef]

9. Garaga R, Kota SH. Characterization of PM10 and impact on human health during the annual Festival of Lights (Diwali). JH\&P 2020;8(20):181-206. [CrossRef] 
10. Hirai K, Yamazaki Y, Okada K, Furuta S, Kubo K. Acute eosinophilic pneumonia associated with smoke from fireworks. Intern Med 2000:39(5);401-3. [CrossRef]

11. Becker J M, Iskandrian S, Conkling J. Fatal and near-fatal asthma in children exposed to fireworks. Ann Allergy Asthma Immunol 2000:85:512-3. [CrossRef]

12. Berdibek ZD. Ottoman entertainment culture in the eyes of other. Journal of Ottoman Legacy Studies 2017:4(8):37-58.

13. Durdu M, Cantürk N. Potansiyel yaralama etkileri açısından havai fişekler. Adli Tıp Bülteni 2017;22(2):101-8. [CrossRef]

14. Erdoğan A, Karardıç H, Yavuz M, Karaardıç LÖ. Manavgat/Side yöresinde havai fişek gösterilerinin fauna elemanları üzerine etkisi. Tabiat ve İnsan 2008:42(2);2-7.

15. Karaçalı M. Düğün salonlarında kullanılan havai fişeklerin iç ortam havasındaki ince partiküllerde metal içeriklerinin belirlenmesi. Yayınlanmamış yüksek lisans tezi. Bursa Uludağ Üniversitesi Fen Bilimleri Enstitüsü; 2019.

16. Sakarya Rehberi. Available at: https://www.sakarya.bel.tr/tr/ Sayfa/sakaryarehberi/1. Accessed Jul 25, 2020.

17. Sakarya'da Patlama. Available at: https://www.cnnturk.com/ turkiye/son-dakikasakaryada-fabrikada-patlama. Accessed Jul 25, 2020.

18. T.C Çevre ve Şehircilik Bakanlığı, Hava izlem. Available at: https://www.havaizleme.gov.tr/. Accessed Jul 25, 2020.

19. Seidel DJ, Birnbaum AN. Effects of Independence Day fireworks on atmospheric concentrations of fine particulate matter in the United States. Atmospheric Environment 2015;115:192-8. [CrossRef]

20. Retama A, Neria-Hernández A, Jaimes-Palomera M, RiveraHernández $O$, Sánchez-Rodríguez $M$, López-Medina $A$, et al. Fireworks: A major source of inorganic and organic aerosols during Christmas and New Year in Mexico city. Atmospheric Environment: X 2019;2:100013. [CrossRef]
21. Chatterjee A, Sarkar C, Adak A, Mukherjee U, Ghosh S, Raha S. Ambient air quality during Diwali festival over Kolkata - A Mega-City in India. Aerosol Air Qual Res 2013:13(3);1133-44.

22. Moreno T, Querol X, Alastuey A, Minguillon MC, Pey J, Rodriguez $S$, et al. Recreastional atmospheric pollution episodes: inhalable metalliferous particles from firework displays. Atmospheric Environment 2007;41:913-22. [CrossRef]

23. Resmi CT, Nishanth T, Satheesh Kumar MK, Balachandramohan $\mathrm{M}$, Valsaraj KT. Temporal changes in air quality during a festival season in Kannur, India. Atmosphere 2019:10(3);13757. [CrossRef]

24. Castro A, Calvo Al, Alves C, Alonso-Blanco E, Coz E, Marques $\mathrm{L}$, et al. Indoor aerosol size distributions in a gymnasium. Sci. Total Environ 2015;524:178-86. [CrossRef]

25. UNICEF. The Impact of air pollution on children. UNICEF; 2016. Clear the air for children. Available at: https://www.unicef. org/media/60106/file. Accessed Jul 30, 2020.

26. Lu F, Xu D, Cheng Y, Dong S, Guo C, Jiang X, et al. Systematic review and metaanalysis of the adverse health effects of ambient PM2.5 and PM10 pollution in the Chinese population. Environ Res 2015;136:196-204. [CrossRef]

27. Annesi-Maesano I, Moreau D, Caillaud D, Lavaud O, Moullec YL, Taytard A, et al. Residential proximity fine particles related to allergic sensitisation and asthma in primary school children. Respir Med. Respir Med 2007;101(8):1721-9. [CrossRef]

28. Petroeschevsky A, Simpson RW, Thalib L, Rutherford S. Associations between outdoor air pollution and hospital admissions in Brisbane, Australia. Arch Environ Health 2001;56(1):37-52.

29. Habertürk. Son dakika haberi Sakarya'da havai fişek fabrikasında patlama! 3 gözaltı kararı!. Available at: https:// www.haberturk.com/son-dakika-haberi-sakarya-da-havaifisek-fabrikasinda-patlama-2732523. Accessed Jul 30, 2020. 